\title{
Calibration of channel roughness in intermittent rivers using HEC-RAS model: case of Sarimsakli creek, Turkey
}

\author{
Mehmet Ardıçlıoğlu ${ }^{1}$ Alban Kuriqi ${ }^{2}$
}

C) Springer Nature Switzerland AG 2019

\begin{abstract}
Natural channel's roughness determination constitutes one the most challenging procedure towards the development of hydraulic models for flood prediction and flood hazard mapping. Therefore, it is essential to calibrate and validate the channel's Manning's $n$ roughness coefficient using simulation models. In this study, we calibrated and validated Manning's $n$ roughness coefficient using HEC-RAS for Sarimsakli creek that is tributary of the Kizilirmak river in central Anatolia, Turkey. For calibration of Manning's $n$-values, six different flow regimes were considered based on mean daily flow records between 2005 and 2010. We found that calculated water surface profiles for different Manning's $n$ are slightly lower than the measured one, that indicates a continuous underestimation of the roughness coefficient $n$ by the model. Therefore, our results suggest that higher values of Manning's $n$ should be considered in case of the intermittent rivers. A polynomial relationship was proposed between roughness values and Froude numbers. Finally, a linear relation was established between calculated and measured Manning's $n$ roughness coefficient. Nevertheless, results showed that careful attention should be given to higher $n$-values because the differences between HEC-RAS and Manning's $n$ becomes larger. Solution-oriented results obtained and the methodology applied to the Sarimsakli creek may serve as a practical reference for HEC-RAS modelling and flood prediction in intermittent rivers.
\end{abstract}

Keywords Ecohydraulics $\cdot$ Flood risk · Flooding $\cdot$ Hydraulic model $\cdot$ Riparian vegetation $\cdot$ River restoration

\section{List of symbols}

HEC-RAS River Analysis System (RAS) developed by Hydrologic Engineering Center (HEC) of U.S. Army Corps of Engineers

$1 D / 2 D$ One dimensional/two dimensional

$n \quad$ Manning's roughness coefficient $\left(\mathrm{s} / \mathrm{m}^{1 / 3}\right)$

$Q \quad$ Flow discharge $\left(\mathrm{m}^{3} \mathrm{~s}^{-1}\right)$

$V \quad$ Flow velocity $\left(\mathrm{m} \mathrm{s}^{-1)}\right.$

A Submerged cross-section's area $\left(\mathrm{m}^{2}\right)$

$R \quad$ Hydraulic radius $(\mathrm{m})$

$P \quad$ Wetted perimeter $(\mathrm{m})$

$S_{\text {ws }} \quad$ Water surface slope $(\mathrm{m} / \mathrm{m})$

$\mathrm{Fr} \quad$ Froude number (-)

$g \quad$ Gravitational acceleration $\left(\mathrm{ms}^{-2}\right)$

$S \quad$ Friction slope $(\mathrm{m} / \mathrm{m})$

$\varepsilon \quad$ Average difference (\%)

$\begin{array}{ll}h_{\text {meas }} & \text { Measured depth }(\mathrm{m}) \\ h_{\text {calc }} & \text { Calculated depth }(\mathrm{m}) \\ S_{0} & \text { Channel bottom slope }(\mathrm{m} / \mathrm{m}) \\ S_{f} & \text { Friction slope }(\mathrm{m} / \mathrm{m}) \\ t & \text { Time }(\mathrm{s}) \\ q_{l} & \text { Lateral inflow }\left(\mathrm{m}^{3} \mathrm{~s}^{-1}\right) \\ x & \text { Longitudinal coordinate }(\mathrm{m})\end{array}$

\section{Introduction}

Among various channel's hydraulic parameters, the channel's roughness plays a crucial role in the study of open-channel flow, particularly in the hydraulic modelling of natural rivers. Channel roughness of the natural rivers it varies among cross-sections and along the

Alban Kuriqi, alban.kuriqi@tecnico.ulisboa.pt | ${ }^{1}$ Kayseri, Turkey ${ }^{2}$ CERIS, Instituto Superior Técnico, Universidade de Lisboa, Lisbon, Portugal.

SN Applied Sciences (2019) 1:1080 | https://doi.org/10.1007/s42452-019-1141-9 
longitudinal direction of the river [1, 2]. It changes in space and time and depends upon some factors like; river bed geomorphology, vegetation cover, channel's local irregularities and alignment $[3,4]$. The roughness coefficient is a significant parameter for calibrating and validating the hydrodynamic models in the case of open channel modelling and in particular, potential floodplain mapping [5]. Floodplain modelling constitutes several different areas, including preparation of comprehensive floodplain studies related to transportation infrastructure (e.g., culvert and bridges), floodway development, and structural and non-structural solutions related to the flooding problems. Model-based floodplain studies provide water surface profiles and floodplain maps for landuse planning and flood-prone areas [6-8]. It is import to mention that floodplain studies are complex cases where roughness coefficient should be set in part rather than one representative value for the entire river reach [9].

The Manning roughness coefficient $n$ in natural channels is difficult to determine in the field. A summary of the empirical equations for assessing Manning's roughness coefficient can be found in Papaioannou et al. [5]. Literature suggests different ways of estimation of Manning's roughness coefficient, but in general, they can be applied to channels in normal conditions such as steady uniform flow [10]. However, natural channels have dimensional heterogeneity, both regarding cross-sections and longitudinal direction. Therefore, several aspects related to inertia, diffusive and kinematic waves are neglected in Manning's equation [11]. Hydraulic models like HEC-RAS provide access to quickly modify the critical parameters, such as Manning's $n$, by also performing sensitivity analysis, thus assessing the importance of each parameter and providing water surface elevations close to the observed one $[12,13]$. The understanding of the river's hydraulic behaviour has been significantly enhanced in recent years thanks to computer programs that simulate the hydraulic behaviour and other river's related processes as well. Detailed information about the most popular hydraulic models used for open channel modelling and advantages/disadvantages between them is reported by Leandro et al. [14]. Computer hydraulic models are being used all over the world to understand the magnitude and frequency patterns better by assisting in the preparation of potential flood scenarios, at vulnerable zones [12]. HEC-RAS, a worldwide applied hydraulic model, developed by U.S. Army Corps of Engineers, it computes water surface profile and several hydraulic parameters for both steady and unsteady, 1D/2D dimensional, gradually varied flow in both natural and human-made channels [15]. Also, HECRAS allows for sediment transport/mobile bed computations and water temperature modelling as well $[9,15]$.
To properly evaluate the sensitivity of Manning's $n$ roughness coefficient using HEC-RAS, it is necessary to model a river with relatively uniform geometric and hydraulic conditions [5]. The idea is to limit the potential variance of other relevant hydraulic variables. Therefore, the channel under consideration should be relatively straight, neither contracting nor expanding. Channel cross-sections need to be stable. High watermarks must be present near the surveyed cross-sections, and stream discharge data is needed at or near the study site. Many types of research applied the HEC-RAS model to estimate roughness either in the main channel or floodplain and in different climate conditions. Ramesh et al. [1] estimated single-channel roughness value for open channel flow using optimisation method, taking the boundary condition as constraints.

Moreover, Hicks and Peacock [11] and Kuriqi and Ardiçlioğlu [4] used Manning's $n$ roughness coefficient as the calibration parameter and found that performance of HEC-RAS was as good as with another one-dimensional model through its application respectively to the Peace River in Alberta (Canada) and Loire river in France. Whereas, Timbadiya et al. [16] developed an integrated hydrodynamic model for the lower Tapi River, India. Firstly, the one-dimensional hydrodynamic model was calibrated for Manning's $n$ roughness of river channel and subsequently one-dimensional, and two-dimensional integrated MIKE 11 hydrodynamic models were used to ascertain the sensitivity of Manning's $n$ at the coastal part of the floodplain depth in lower Tapi River. Mowinckel [17] used the HEC-RAS to modify the downstream artificial reach of San Jose Creek in Goleta, California, to improve the flood conveyance capacity of the reach. This study was an effort to suggest a channel geometry that could facilitate the flow discharge of a 100-year flood better than the existing channel, thus preventing damages like those caused by historical flood events by affecting the surrounding area.

Parhi et al. [18] applied the HEC-RAS to calibrate the channel roughness coefficient along the river Mahanadi, Odisha. The authors concluded that Manning's $n$-value of 0.032 gives the best result for Khairrmal to Munduli reach of the Mahanadi River. The calibrated model, regarding channel roughness, was used to simulate the flood event for the year 2006 in the same river reach. The performance of the calibrated and validated HECRAS based model was tested using Nash and Sutcliffe efficiency, which eventually showed high efficiency. Also, Timbadiya et al. [16] used two experimental data on the physical model of lower Tapi River, optimised Manning's $n$ roughness coefficient for efficient prediction of the flood in lower Tapi River using HEC-RAS. They concluded that calibrated HEC-RAS model for a specific prototype has been able of providing reasonable results 
in simulating the flood event for the year 2003 at lower Tapi River. While Boulomytis et al. [19] compared HECRAS and MIKE11 models for Bashar River and observed slight differences between the results, they detected that selection of the same Manning's $n$ roughness coefficients for different hydraulic models causes an error in the flow simulation process. Therefore, close attention should be given to Manning's $n$ roughness calibration when different hydraulic models are applied. Gunawan et al. [20] propose to test the use of HEC-RAS software on a river with scarce flow data measurements and designing specific height and location of flood protection embankments to Air Manjuto Bengkulu province. The Rational Method was used to calculate flood discharge for different return periods $2,5,10,25,50$ and 100 years considering long records of mean daily flow data. Water profile, height and position of the embankment was analysed using computer program HEC-RAS. Although there is a handful of studies related predominantly to perennial rivers, to the best of our knowledge, at least in Turkey, there is no study regarding the estimation of the Man$n$ ning's $n$ roughness coefficient in intermittent rivers using hydraulic models. Intermittent rivers are characterised by substantial variability, and during a specific period of the year, they go completely dry [21]. Nevertheless, it is essential to study this type of river because they are often exploited for irrigation or hydropower production. In such circumstances correct determination of the maximum water level is crucial information for sizing and positioning of the respective hydraulic structures and also to establish adequate environmental flows [22].

Furthermore, because this type of rivers goes dry during a certain period of the year, they are characterised by overgrown vegetation, mainly macrophytes, which influence the roughness of the river reach significantly [23, 24]. Because of several factors influencing the Manning $n$ roughness coefficient, accurate measurement is a challenging task, and it demands very extensive work. Thus, a well-established equation facilitates computation of the Manning's coefficient $n$ for any discharge at any location [25]. Therefore, the main objective of this study is to investigate how the roughness coefficient is affected due to continues change of the stream conditions and establishing a reasonable relationship between measured and HECRAS model results regarding the roughness coefficient to estimate as accurate as possible the water surface profile.

The paper is organised as follows: Sect. 2 presents information about the study site, field measurements, hydraulic modelling, and the way how these procedures were conducted. Section 3 shows the main results obtained from this study and discuss the relevance of the main findings. Finally, the main conclusion and some outlook for future works are given in Sect. 4.

\section{Materials and methods}

\subsection{Field measurements}

Field measurements and flow characteristics have been carried out at Sarimsakli creek, which is a tributary of Turkey's longest river Kizilirmak, located in the central Anatolia. The measurement station is located on the upstream side of the east of Kayseri, which is one of the important cities of inner Anatolia. Floods events occur very often in this region, which has a semi-arid, continental climate, especially during the spring season. To prevent flood damages at Kayseri area, the flow in Sarimsakli creek should be continuously monitored although it is an intermittent river. Sarimsakli creek is prone to several flash floods during the year, especially flash floods during the early summer season [26]. Fields measurements were obtained at Barsama station on Sarimsakli creek, which runs out to Kizilirmak river (Fig. 1).

Also, to understand the influence of the vegetation, Barsama station was visited six different times between 2005 and 2010, as given in Table 1. The water levels were below the bank-full stage at each measurement. During flow measurements, according to the water surface width, cross-sections were split into several vertical slices for each flow condition. Point velocities were measured in the vertical direction, starting $4 \mathrm{~cm}$ from the river bed for each vertical profile [27]. A typical representative cross-section typology obtained during the measurements is given in Fig. 2 .

Cross-sections velocities were measured almost in the middle of the river reach, at $30 \mathrm{~m}$ distance (Fig. 4). Channel bed and water surface slopes were determined by measuring elevations with a level for different numbers of the upstream and downstream cross-sections. Namely, upstream of the station, water depth was measured at 10 verticals per cross-section with $3 \mathrm{~m}$ intervals for given slope. While downstream of the station, water depth was measured at 12 verticals per cross-section, again at $3 \mathrm{~m}$ interval for the given slope. For all flow conditions, bed and water surface slopes were found close to each other, and nearly uniform flow condition was observed. The hydraulic regime in the creeks is dynamic and vary depending on time and space. The channel cross-sections profiles and slope vary depending on the flow regime characteristics which induce continues changes of the river geomorphology. For this purpose, measurements were performed in six different periods and current states as well. Inevitably, considering the different current characteristics will affect the sensitivity of the study.

The velocity measurements were conducted with "SonTek/YSI FlowTracker Handheld Acoustic Doppler 


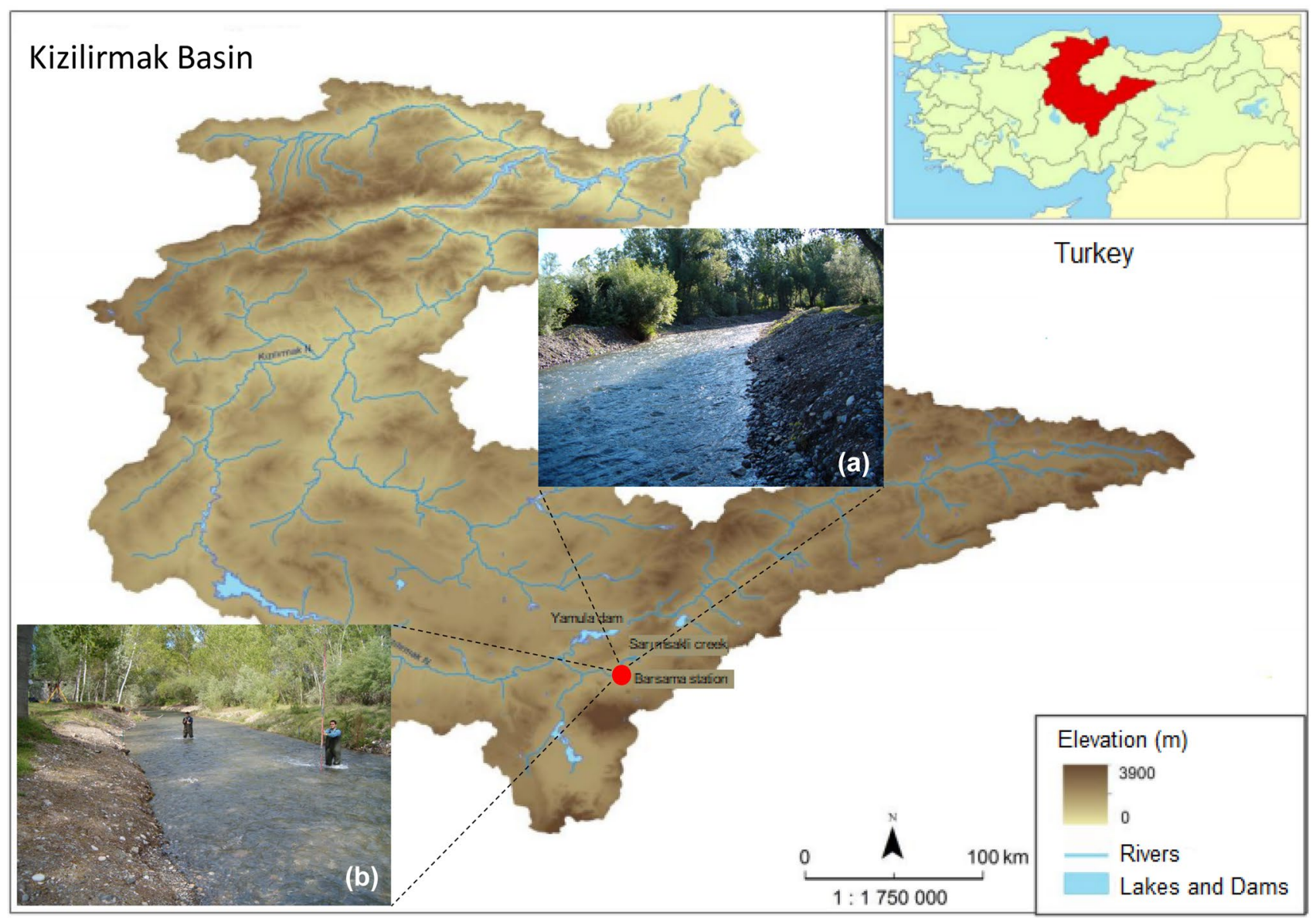

Fig. 1 Kizilirmak river basin with the location of a measuring station, Barsama and $\mathbf{b}$ a random picture was taken during the field measurement day

Table 1 Flow properties obtained during the field measurements and some results obtained after hydraulic modelling

\begin{tabular}{llllllllllll}
\hline No & Date & $\mathrm{Q}\left(\mathrm{m}^{3} \mathrm{~s}^{-1}\right)$ & $\mathrm{V} \mathrm{m} \mathrm{s}^{-1}$ & $\mathrm{R}(\mathrm{m})$ & $\mathrm{S}_{\mathrm{ws}}(\mathrm{m} / \mathrm{m})$ & $\mathrm{Fr}$ & $\mathrm{n}\left(\mathrm{s} / \mathrm{m}^{1 / 3}\right)$ & $\begin{array}{l}\text { Manning }(\mathrm{n}) \\
\text { HEC-RAS }\end{array}$ & $\varepsilon(\%)$ Man. & $\varepsilon(\%) \mathrm{HEC-RAS}$ \\
\hline Barsama 1 & 28.May.05 & 1.81 & 0.89 & 0.24 & 0.0091 & 0.57 & 0.042 & 0.050 & 2.65 & 2.07 \\
Barsama 2 & 19.May.06 & 2.44 & 1.05 & 0.25 & 0.0036 & 0.66 & 0.023 & 0.020 & 4.09 & 1.45 \\
Barsama 3 & 19.May.09 & 3.93 & 1.21 & 0.34 & 0.0094 & 0.66 & 0.039 & 0.042 & 5.03 & 4.74 \\
Barsama 4 & 31.May.09 & 0.96 & 0.59 & 0.19 & 0.0092 & 0.43 & 0.054 & 0.050 & 4.04 & 3.77 \\
Barsama 5 & 24.Mar.10 & 1.50 & 0.80 & 0.21 & 0.0097 & 0.55 & 0.044 & 0.040 & 4.06 & 3.83 \\
Barsama 6 & 18.Apr.10 & 2.148 & 0.86 & 0.28 & 0.0122 & 0.52 & 0.055 & 0.065 & 3.89 & 2.59 \\
Mean & 0.043 & 0.045 & 3.96 & 3.08 & & & & & & & \\
\hline
\end{tabular}

Velocimeter (ADV)" (https://www.sontek.com/flowtracke r). The flow characteristics are summarised in Table 1.

Where $Q$ is the cross-sectional discharge calculated by velocity-area method, $V(=Q / A)$ is the mean velocity, $A$ is the submerged cross-section's area, $R$ is the hydraulic radius, $P$ is the wetted perimeter, $S_{w s}$ is the water surface slope, $\operatorname{Fr}\left(=v /(g R)^{0.5}\right)$ is the Froude number, and $g$ is the gravitational acceleration. The well-known Manning's equation relates flow velocity $(V)$, the friction slope $(S)$, and hydraulic radius $(R)$ through the Manning's roughness coefficient $n$. The equation can be written as (Eq. 1):

$V=\frac{1}{n} R^{2 / 3} S^{1 / 2}$

The Manning's roughness coefficient $n$-value can be determined after the $V, R$, and $S$ are known. The average 
Fig. 2 A representative crosssection (B-B, Fig. 4) from the study site of the Sarimsakli creek. The main channel of Sarimsakli creek is characterised by vegetation which during low flow or and dry period is overgrown by occupying almost at $30 \%$ of the main channel

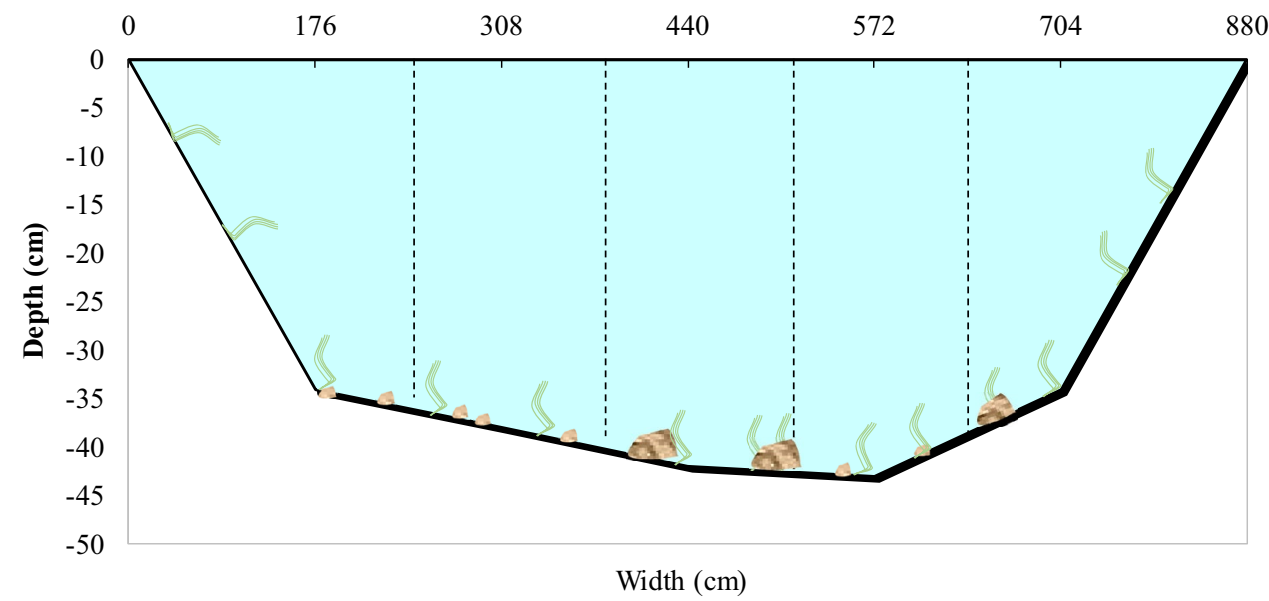

difference $(\varepsilon)$ between the measured $\left(h_{\text {meas }}\right)$ and calculated $\left(h_{\text {calc }}\right)$ water surface depth was computed by using Eq. 2.

$\varepsilon(\%)=\left|\left(\left(h_{\text {meas }}-h_{\text {calc }}\right) / h_{\text {meas }}\right)\right| * 100$

\subsection{Hydraulic modelling}

The gradually varied flow was simulated using the HECRAS 1D model, which simulate the hydraulic regime by solving Saint-Venant equations (Eqs. 3-4).

- Continuity equation

$$
\frac{\partial A}{\partial t}+\frac{\partial Q}{\partial x}=q_{l}
$$

- Momentum equation

$$
\frac{\partial Q}{\partial t}+\frac{\partial\left(Q^{2} / A\right)}{\partial x}+g A \frac{\partial H}{\partial x}+g A\left(S_{o}-S_{f}\right)=0
$$

where $H$ is the water surface elevation; $t$ denotes temporal coordinates; $x$ represents the longitudinal coordinate; $q_{\text {I }}$ is lateral inflow from tributaries, which in our case is $0 ; S_{0}$ is the channel bottom slope, and $S_{f}$ is the friction slope. Saint-Venant equations were solved using the four-point implicit box finite-difference principle [15]. Although finite-difference principle has limited ability in conducting the transitions between subcritical and supercritical flow regime because this process requires a different solution algorithm for different flow conditions. Nevertheless, the above limitation is overcome by using a mixed-flow regime option in the HEC-RAS model; by doing this, HECRAS can provide patching solution in the sub-zones of the river reach $[11,15,16]$. To conduct the hydraulic simulation following input data are needed: channel geometry; boundary conditions; discharge data; and roughness [11,
15]. During the simulation stage, Manning's $n$-values were introduced according to Brunner [15] and Arcement, Schneider [9]. Since the flow condition at study river reach was nearly steady uniform, the downstream boundary condition was set at normal. The river reach geometry in the HEC-RAS was drawn based on the geometry data obtained in the field, considering the most representative cross-sections. Then, the calculated water depth in the HEC-RAS was compared with the observed one.

\section{Results and discussion}

Deep understanding of the fluvial processes, particularly in the case of highly fluctuating rivers is essential because water is one of the main drivers of several abiotic and biotic processes [25]. In this context, hydraulic models are being considered more and more as useful tool for water management and playing. The Manning roughness equation is one of the most commonly used empirical equation for open channel flow discharge calculations, flood forecasting and flood inundation mapping studies. Although they are simple, none of those empirical equations poses the ability for universal application, namely they are site-specific.

Furthermore, they are all very sensitive to the roughness parameters and are not easy to determine $[9,25]$. The calibration of water surface profiles includes the choice of an appropriate Manning's $n$-value, such that simulated water depth from the HEC-RAS model should be close to the observed water depth along the river. In this study, Manning's $n$-values wide-ranging between 0.023 and 0.055 for six different flow conditions (Table 1), this is due to river bed vegetation among other, which has a significant influence on the overall roughness [19]. The average value of the Manning roughness coefficient for six measurements at Barsama station is found to be $\approx 0.043$. Similar 
results were obtained by Boulomytis et al. [19] in the case of the vegetated channel.

When Manning's $n$ and Froude numbers are plotted on the graph for each flow conditions, it is observed that there is a polynomial relationship $\left(R^{2}=0.77\right)$ between them (Fig. 3).

Manning's $n$ can be determined using a second-order polynomial equation given below (Eq. 5).

$n=-0.365 F r^{2}+0.291 F r-0.003$

Using the Manning's $n$ roughness coefficients, water surface profiles were determined with HEC-RAS along the measured cross-sections for six different flow conditions.

Figure 4 shows Barsama 6 measured flow water surface profiles and calculated one with HEC-RAS by using Manning's $n$ coefficient. As shown in Fig. 4, the calculated water surface profiles are slightly lower than the measured one. The average difference between the measured and calculated water surface heights of the sections studied in this measurement is $3.89 \%$. This difference in water depth

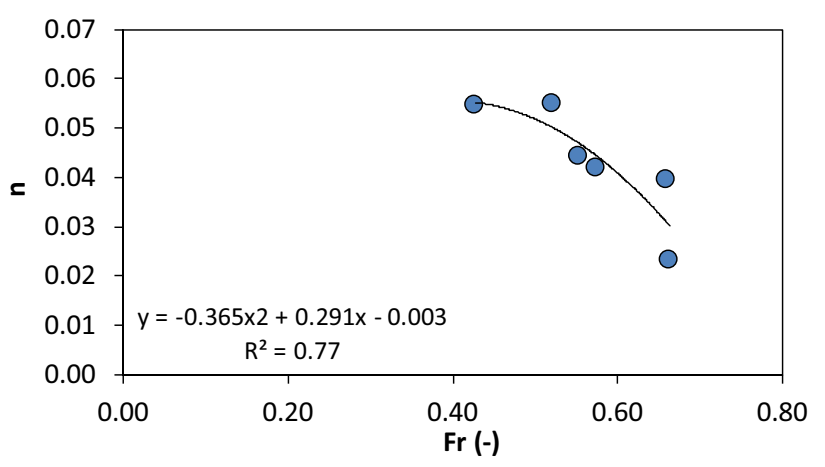

Fig. 3 Polynomial relation between Manning's $n$ and Fr number occurs mainly due to the presence of micro patches in the river bed, which in reality have different roughness but very challenging to model correctly in the HEC-RAS [28, 29]. The differences in the water profiles and measured profiles calculated by Manning's $n$-values of the other five measurements are given in Table 1 . The mean difference of six measurements was determined as $\approx 3.96 \%$ (Table 1 ).

The roughness values that give the nearest water surface profile calculated using the HEC-RAS to the measured profile was determined as $\approx 0.065$ for Barsama 6 flow condition. The difference between the observed and computed water profile in the analysed section is $2.59 \%$. While the water surface profile calculated for $n=0.065$, as seen in Fig. 4, is closer to the measured values.

Roughness coefficients, which gives the closest value to the measured profiles of those determined by HEC-RAS, are calculated, and given in Table 1. As shown in these values, HEC-RAS roughness parameters vary between 0.020 and 0.065 for six different flow conditions. A similar range of roughness was observed by other authors as well [2, $19,30]$. Average of the roughness coefficients determined by the HEC-RAS for six measurements is found as $\approx 0.045$. This value is slightly more significant than the average of the Manning's $n$ roughness coefficient for the six measurements. The differences in the measured and calculated water profiles by the HEC-RAS, also $n$-values of the other five measurements are given in Table 1. The mean difference of six measurements was determined as $\approx 3.08 \%$ (Table 1). As can be understood from this value, the roughness values estimated with HEC-RAS could more accurately determine the water surface profiles. Mowinckel [17] concluded similar results with the results presented in this study.
Fig. 4 Measured and computed water surface profiles for station Barsama 6. Channel bed is characterised by vegetation, mainly macrophytes and pebbles of different sizes

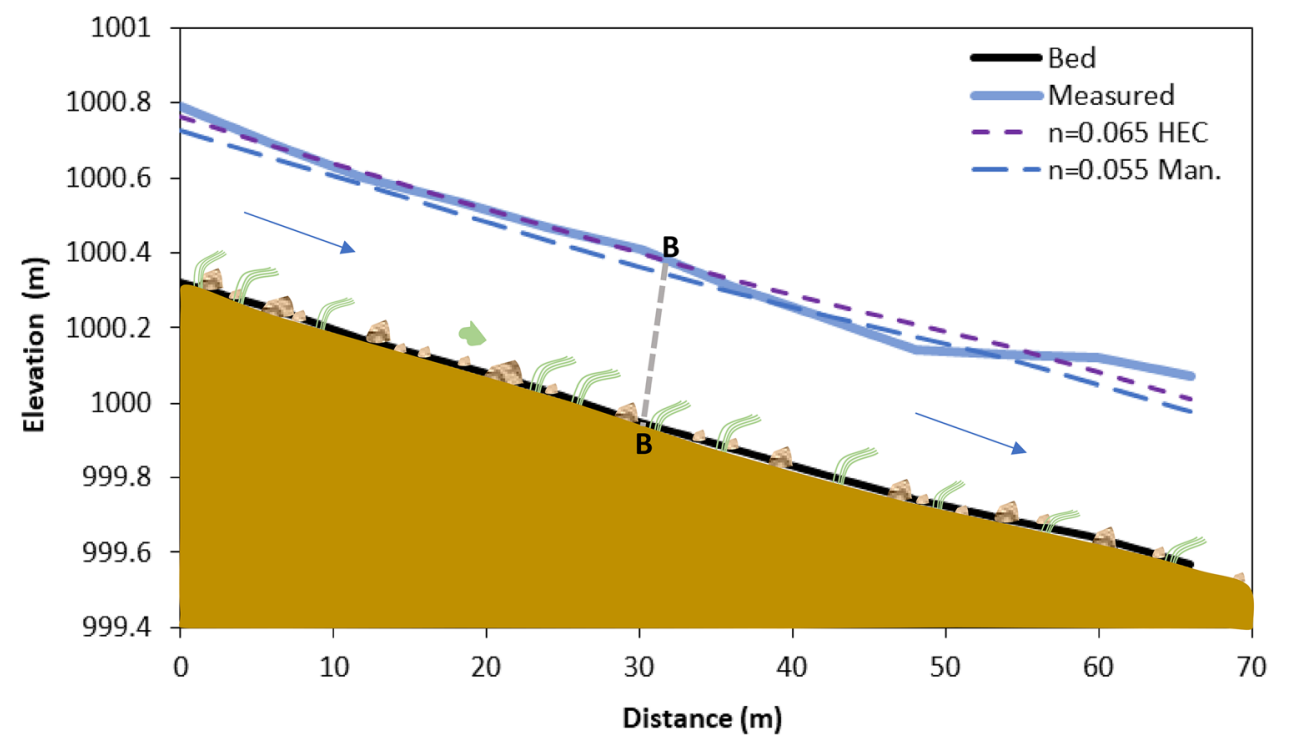




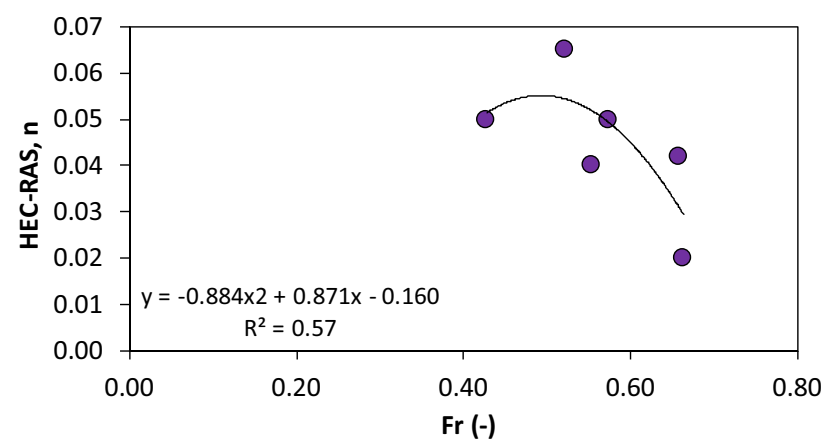

Fig. 5 Polynomial relation between HEC-RAS $n$ and Fr number

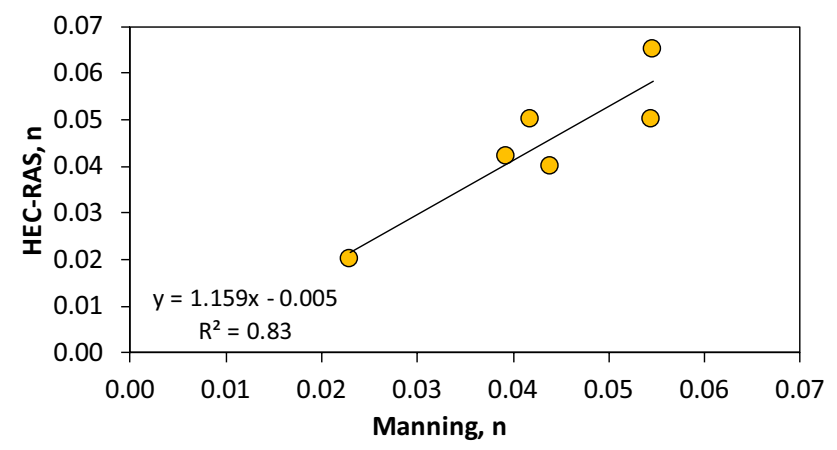

Fig. 6 HEC-RAS $n$ and Manning $n$ relation

When HEC-RAS $n$-values and Froude numbers are plotted on the graph for each flow conditions, a similar polynomial relationship was observed between them (Fig. 5). This second-order polynomial equation is given below (Eq. 6). Determination coefficient of this equation is found as $\mathrm{R}^{2}=0.57$, which is smaller than the Manning's $n$ relation. As mentioned above, this difference occurs because of roughness generalisation in the HEC-RAS model, difficulties of micro patches modelling [28] and also irregularities present in the river [13].

$n=-0.884 F r^{2}+0.871 F r-0.160$

Nevertheless, as seen in Fig. 6, overall there is a strong relation between Manning's $n$ and HEC-RAS $n$, where the determination coefficient is, $R^{2}=0.83$. This result indicates that although some hydraulic parameters (e.g., Fr) were not strongly correlated with Manning's $n$, still HEC-RAS model as one of the most frequently upgraded hydraulic model [15], is capable to accurately estimate the $n$-values $[4,19]$.

The relation between Manning's $n$ and HEC-RAS $n$ can be written as given in the equation below (Eq. 7).

$n_{\text {HEC-RAS }}=1.159 n_{\text {Manning }}-0.005$
Thus, by using Eq. 5, roughness parameter $n$ can be calculated on flow Froude numbers. Moreover, by using Eq. 7, HEC-RAS $n$ can be calculated easily and more precisely.

Furthermore, from this plot, we can conclude that for higher $n$-values, the differences between HEC-RAS and Manning's $n$ is increasing. Estimation of Manning's roughness coefficient in natural channels is a challenging process because of the flow discharge and also channel geomorphology features (i.e., local slope, cross-section shape) change in space and time [11]. Furthermore, the estimation procedures become even more complicated when rivers are characterised by high flow discharge seasonality and overgrown vegetation in the main channel $[19,30]$. These circumstances make the accurate estimation of the Manning's roughness coefficient more complex. However, as reported by several authors [1, 3, 4, 25], HEC-RAS represents a powerful tool that has the capability of providing robust results about Manning's $n$-value estimation. Although there is a lack of literature concerning the estimation of the Manning's $n$ roughness coefficient in intermittent rivers, this study shows quite rational results in this regard. The methodology applied in this study and also solution-oriented results might help water managers and hydraulic modellers to estimate Manning's $n$-values in intermittent rivers regardless climate conditions, and consequently allowing them to make a more accurate prediction concerning mainly flood inundation hazard and so on.

\section{Conclusions}

The present study attempted to calibrate the channel roughness coefficient Manning's $n$-value along the Sarimsakli creek, through simulation of water depth using HEC-RAS Model. For this purpose, six different flow conditions were considered, and the following results can be summarised:

- Average of the Manning roughness coefficients are found as 0.043 for six measurements at Barsama station.

- The average difference between the measured and calculated water surface heights of six measurements was determined as $3.96 \%$.

- Analysis of measured data in the creek indicates that Manning's $n$-values wide-ranging between 0.023 and 0.055 for six different flow conditions.

- Using HEC-RAS package, mean roughness coefficients are found as 0.045 for six measurements at Barsama station.

- The roughness values estimated with HEC-RAS can more accurately determine the water profile profiles. 
The average difference of six measurements was determined as $3.08 \%$

This work demonstrates the capability of the HEC-RAS model to analyses the flow regime in Sarimsakli creek by using distributed data obtained from several cross-sections upstream and downstream of the reference station. So, a part of the model performance and regardless the type of the model that we chose to conduct the analysis, still we should be aware of the parameters required by a model and interpretation of the analysis results obtained by the model. It is worth remarking that the computed values are affected by several uncertainties, including but not limited to the simplification of the geometry of the cross-section, accuracy of the velocity measurement, accuracy, representativeness of the water surface slope and so on. Moreover, the real water surface profile could also be affected by small localised changes in geometry and $2 \mathrm{D}$ effects due to the curvature of the channel. Concerning the future work, it would be interesting of investigating the economic impact that has the accurate estimation of the Manning's $n$ roughness coefficient in developing detailed flood hazard maps or on infrastructure design (e.g., culvert, bridges).

Acknowledgements Authors are grateful to the Editor's and the Reviewers comments, which significantly improved the current version of the paper.

Funding Alban Kuriqi was supported by a PhD scholarship granted by Fundação para a Ciência e a Tecnologia, I.P. (FCT), Portugal, under the PhD Programme FLUVIO-River Restoration and Management, grant number: PD/BD/114558/2016.

\section{Compliance with ethical standards}

Conflict of interest The authors declare that they have no conflict of interest.

\section{References}

1. Ramesh R, Datta B, Bhallamudi SM, Narayana A (2000) Optimal estimation of roughness in open-channel flows. J Hydraul Eng 126(4):299-303. https://doi.org/10.1061/ (ASCE)0733-9429(2000)126:4(299)

2. Szomorová L, Halaj P (2015) Numerical simulations in the Mala Nitra stream by 1D model. Acta Scientiarum Polonorum Formatio Circumiectus 14(2):185-194. https://doi.org/10.15576/asp. $\mathrm{Fc} / 2015.14 .2 .185$

3. Serede I J (2015) Calibration of channel roughness coefficient for Thiba Main Canal Reach in Mwea irrigation scheme, Kenya. Hydrology 3(6):55-65. https://doi.org/10.11648/j.hyd.20150 306.11

4. Kuriqi A, Ardiçlioğlu M (2018) Investigation of hydraulic regime at middle part of the Loire River in context of floods and low flow events. Pollack Periodica 13(1):145-156. https://doi. org/10.1556/606.2018.13.1.13
5. Papaioannou G, Vasiliades L, Loukas A, Aronica GT (2017) Probabilistic flood inundation mapping at ungauged streams due to roughness coefficient uncertainty in hydraulic modelling. Adv Geosci 44:23-34. https://doi.org/10.5194/adgeo -44-23-2017

6. Selenica A, Kuriqi A, Ardıçlığlu M (2011) Risk assessment from flooding's in the rivers of Albania. In: Paper presented at the International Balkans Conference on Challenges of Civil Engineering, BCCCE, Tirana, Albania, 19-21, May

7. Teng J, Jakeman AJ, Vaze J, Croke BFW, Dutta D, Kim S (2017) Flood inundation modelling: a review of methods, recent advances and uncertainty analysis. Environ Model Softw 90:201-216. https://doi.org/10.1016/j.envsoft.2017.01.006

8. Kuriqi A, Ardiçlioglu M, Muceku Y (2016) Investigation of seepage effect on river dike's stability under steady state and transient conditions. Pollack Periodica 11(2):87-104. https://doi. org/10.1556/606.2016.11.2.8

9. Arcement GJ, Schneider VR (1989) Guide for selecting manning's roughness coefficients for natural channels and flood plains, vol I. United States Government Printing Office, Washington, DC. Doi: https://doi.org/10.3133/wsp2339

10. Ardıçlıoğlu M, Selenica A, Özdin S, Kuriqi A, GençO (2011) Investigation of average shear stress in natural stream. In: Paper presented at the International Balkans Conference on Challenges of Civil Engineering, BCCCE, Tirana, Albania, 19-21, May

11. Hicks FE, Peacock T (2005) Suitability of HEC RAS for flood forecasting. Can Water Resour J 30(2):159-174. https://doi. org/10.4296/cwrj3002159

12. Liu Z, Merwade V (2018) Accounting for model structure, parameter and input forcing uncertainty in flood inundation modeling using Bayesian model averaging. J Hydrol 565:138-149. https:// doi.org/10.1016/j.jhydrol.2018.08.009

13. Vojtek M, Petroselli A, Vojteková J, Asgharinia S (2019) Flood inundation mapping in small and ungauged basins: sensitivity analysis using the EBA4SUB and HEC-RAS modeling approach. Hydrol Res 50(4):1002-1019. https://doi.org/10.2166/ nh.2019.163

14. Leandro J, Chen AS, Djordjević S, Savić DA (2009) Comparison of 1D/1D and 1D/2D coupled (Sewer/surface) hydraulic models for urban flood simulation. J Hydraul Eng 135(6):495-504. https ://doi.org/10.1061/(ASCE)HY.1943-7900.0000037

15. Brunner GW (2016) HEC-RAS river analysis system (trans: Center HE). Doi: https://www.hec.usace.army.mil/software/hec-ras/ documentation.aspx, 5.0 edn. U.S. Army Corps of Engineers, Davis, CA

16. Timbadiya P, Patel PL, Porey P (2011) Calibration of HEC-RAS Model on Prediction of Flood for Lower Tapi River, India. J Water Resour Protect 03(11):805-811. https://doi.org/10.4236/jwarp .2011 .311090

17. Mowinckel E (2011) Flood capacity improvement of San Jose Creek channel using HEC-RAS. Calif Polytech State Univ, California

18. Parhi PK, Sankhua RN, Roy GP (2012) Calibration of channel roughness for Mahanadi River, (India) using HEC-RAS model. J Water Resour Protect 04(10):847-850. https://doi.org/10.4236/ jwarp.2012.410098

19. Boulomytis VTG, Zuffo AC, Dalfré Filho JG, Imteaz MA (2017) Estimation and calibration of Manning's roughness coefficients for ungauged watersheds on coastal floodplains. Int J River Basin Manag 15(2):199-206. https://doi.org/10.1080/15715 124.2017.1298605

20. Gunawan G, Besperi, Surapati A, Lidia A (2016) Water profile estimation on river flood discharge by using HEC-RAS (case study: Air Manjuto River, Bengkulu, Indonesia). In: Paper presented at the international conference on engineering and science for research and development (ICESReD), India 
21. Leigh C, Boulton AJ, Courtwright JL, Fritz K, May CL, Walker RH, Datry $\mathrm{T}$ (2016) Ecological research and management of intermittent rivers: an historical review and future directions. Freshw Biol 61(8):1181-1199. https://doi.org/10.1111/fwb.12646

22. Kuriqi A, Pinheiro AN, Sordo-Ward A, Garrote L (2019) Influence of hydrologically based environmental flow methods on flow alteration and energy production in a run-of-river hydropower plant. J Clean Prod 232:1028-1042. https://doi.org/10.1016/j. jclepro.2019.05.358

23. Brahimi M, Afzalimehr H (2018) Effect of submerged vegetation density on flow under favorable pressure gradient. SN Appl Sci 1(1):57. https://doi.org/10.1007/s42452-018-0052-5

24. Kiss T, Nagy J, Fehervary I, Vaszko C (2019) (Mis) management of floodplain vegetation: the effect of invasive species on vegetation roughness and flood levels. Sci Total Environ 686:931-945. https://doi.org/10.1016/j.scitotenv.2019.06.006

25. De Doncker L, Troch P, Verhoeven R, Bal K, Meire P, Quintelier $J$ (2009) Determination of the Manning roughness coefficient influenced by vegetation in the river Aa and Biebrza river. Environ Fluid Mech 9(5):549-567. https://doi.org/10.1007/s1065 2-009-9149-0

26. Kinaci C, Akbaş H, Aras M (2016) İklim Değişikliğinin Su Kaynaklarina Etkisi Projesi. vol I. T.C. Orman Ve Su İşleri Bakanliği Su Yönetimi Genel Müdürlüğü, Kayseri, Turkey
27. Genc O, Kisi O, Ardiclioglu M (2016) Modeling shear stress distribution in natural small streams by soft computing methods. Geofizika 33(2):137-156. https://doi.org/10.15233/ gfz.2016.33.11

28. Martín-Vide JP, Moreta PJM, López-Querol S (2010) Improved $1-D$ modelling in compound meandering channels with vegetated floodplains. J Hydraul Res 46(2):265-276. https://doi. org/10.1080/00221686.2008.9521860

29. Zeleňáková M, Fijko R, Labant $S$, Weiss E, Markovič G, Weiss R (2019) Flood risk modelling of the Slatvinec stream in Kružlov village, Slovakia. J Clean Prod 212:109-118. https://doi. org/10.1016/j.jclepro.2018.12.008

30. Wang J, Zhang Z (2019) Evaluating Riparian vegetation roughness computation methods integrated within HEC-RAS. J Hydraul Eng 145(6):04019020. https://doi.org/10.1061/(ASCE) HY.1943-7900.0001597

Publisher's Note Springer Nature remains neutral with regard to jurisdictional claims in published maps and institutional affiliations. 